Review of Sociology 28(4): 133-151.

\title{
Commuting to segregation The role of pupil commuting in a Hungarian city: between school segregation and inequality
}

\author{
János Zolnay \\ https://doi.org/10.51624/SzocSzemle.2018.4.6 \\ Manuscript received: 17 May 2017. \\ Modified manuscript received: 3 September 2018. \\ Acceptance of manuscript for publication: 21 December 2018.
}

\begin{abstract}
The paper is written to foster understanding of the function of primary school pupils' high commuting rate in Hungary's towns and cities and its role in the process of school choice. Based on two studies and on data collection covering all primary school pupils in the city of Pécs, I analyzed the pattern, direction and success rate of pupils' efforts to find higher quality schools than their district schools. The aim of the study was to unpack the "commuting games" of the primary schools. Results indicate that, in contrast to national trends, the commuting rate of low-status and Roma primary school pupils is also very high within the city. However, while most of the commuting pupils have managed to enrol in higher quality schools than the ones in the catchment area of their homes, the majority of low-status and Roma commuters appear to be attending lower quality schools than those close to their homes, because prestigious schools informally deter them. My findings challenge the literature which claims that the selection mechanisms of public education are predominantly regulated by the mutual choices of prestigious schools and high-status pupils. Schools and their local or central maintenence agents are unable to control the processes against the background of a centralized system.
\end{abstract}

Keywords: educational segregation; selection; pupils' commuting; spatial and educational inequalities

\section{Introduction ${ }^{1}$ :}

The right-wing liberal concept of society and the reforms that it has inspired are often criticized for creating and introducing a quasi-market system in education (van Zanten 2008). The per-capita-basis allocation of school budgets and other resources encourages schools to consider students their most important resources. This results in competition with two meanings: the aim of "first order" competition is to enrol as many students as possible in order to maximize resources, while "second-order competition" is aimed at enrolling the students considered the most academically able so as to enhance the school's prestige (Gewirtz et al 1995). The possibility of

1 The author thanks Erika Csovcsics and Ágnes Gosztonyi for their generous help and Gábor Havas for his valuable comments on the first draft of this paper. 
school choice necessarily exacerbates inequities everywhere as it pushes schools to sort and select students (Musset 2012).

Nevertheless, the quasi-market system of Britain and the USA which is based on free parental choice and indirect state control should be compared cautiously to the education liberalization that ensued the post-communist transition in countries such as Hungary (Kovai - Neumann 2015). In the communist era, the admission quotas of secondary schools were predominantly determined by the annual decisions of the government, and influential state-owned factories continuously and successfully lobbied for the majority of students to attend vocational schools after finishing their primary education. The post-socialist liberalization of school choice had a significant inclusive effect because secondary admission quotas were no longer determined by the government. However, until the nationalization of schools in 2013, extensive secondary expansion had concealed growing between-school inequalities within public education because, due to a co-financing system, schoolmaintaining municipalities had had a vested interest in maximizing the number of secondary school students and, as a consequence, the proportion of pupils from secondary grammar (gimnázium) and secondary vocational schools (szakközépiskola) that were enrolled steadily increased (Fehérvári et al. 2010). Furthermore, the massive expansion of secondary education greatly improved the chances of disadvantaged and Roma pupils entering into secondary education.

At the same time, the fact that social background significantly determines educational outcomes in Hungary clearly originates from a regulatory system based on unlimited free parental choice at all levels of schooling, the unregulated and informal competition of schools for students, primary schools' informal admission practices, and a diversified school system. One of the main reason for early tracking is that students can apply to eight- or six-year secondary grammar schools at the ages of 10 and 12. In this system, one's school performance and educational chances are predominantly determined by early school choices to a much greater extent than in most OECD countries (OECD 2015). The weak capacity of the educational system to compensate for pupils' disadvantages resulted in the fact that in 2005 nearly 20 percent of the year's cohort left public education having completed no more than eight years of primary school, despite the compulsory school attendance age having been raised from 16 to 18 years in 1996 (Kertesi -Varga 2005).

Given these circumstances, educational authorities cannot uphold a stable and inclusive education system. Depending on their perceived particular interests, schools and parents will undermine its stability.

It is highly doubtful whether a targeted voucher system would be capable of counterbalancing the effect of private schools (Hsieh - Urquiola 2006; Fiske Ladd 2000). Educational systems based on free school choice are often described as "universal" voucher schemes whereby all students are provided with a symbolic voucher which can be "redeemed" at any school in the country, although only district 
schools are obliged to admit pupils without further consideration (OECD 2017). Accordingly, parents choose primary schools for their children based on the schools' perceived quality and social composition. They can put their children's names down for any school they choose to, but pupils only have to be accepted by their catchment area schools. Beyond that, however, it is up to the individual schools, which act within the limits of the places they have available, to decide whether to accept children from outside their area. On the other hand, schools are not only interested in maximizing the number of students, but also in improving or at least defending their prestige and local status by admitting presumably well-performing students. The mutual choices of middle-class parents and prestigious schools ${ }^{2}$ necessarily leads to the unequal distribution of educational services.

Approximately 13-14 percent of students in Hungarian primary schools are Roma (Papp Z. 2015). It is a crucial and open-ended question whether the mutual selection process is basically "colour-blind"; that is, if the ethnicity of students adds to the effect of the ESCS ${ }^{3}$ of Roma parents being lower than average, and if their children's abilities and performance will subsequently also be below average. The literature implies that this is not the case; instead, the symbolic significance of ethnicity is far greater and non-Roma parents simply do not wish their children to attend the same schools or at least the same classes as Roma kids (Kemény et al. 2004; Dupcsik 2009). In the former case, the mutually presumed and perceived ability spectrum of schools and children would result in steady balance and student commuting trends would be predictable.

This dilemma is particularly significant in Hungary, because the impact of parents' ESCS on the educational performance of students is higher than in most OECD countries (Csapó et al. 2014; Radó 2014; Ostorics et al. 2016) and therefore, according to my research experience, the impact of the social background of families is an essential factor in the selection criteria for school principals.

Roma pupils' performance in reading may be explained explicitly by their social status, and their performance in mathematics only slightly lags behind that of nonRoma pupils of similar socioeconomic background. On the other hand, their dropout rate from secondary and vocational schools is significantly higher than that of nonRoma pupils of similar socioeconomic background, and they are less likely to continue their education in secondary schools than their non-Roma peers of similar abilities and results (Kertesi - Kézdi 2010).

High commuting rates are a characteristic feature of public education regimes based on free parental school choice. The high proportion of primary school students who opt for schools outside their catchment zone has been demonstrated in several previous studies ${ }^{4}$ (Havas - Zolnay 2011). It has always been clear that pupil commuting

2 I define parents as middle class if they have an opportunity to choose from the best, or allegedly best schools for their children. I define schools as prestigious if they have the opportunity to admit the best, presumably most academically able pupils.

3 Index of Economic Social and Cultural Status.

4 The commuting rate for primary school pupils who leave their local catchment area was 64 percent in larger Hungarian towns, and only 36 percent opted for their catchment zone school. 
is inherently unequal because pupils of higher status are significantly more likely to commute. ${ }^{5}$ Kertesi and Kézdi (2009) found a strong positive association between the number of schools in a vicinity and the commuting rates of middle class children, ${ }^{6}$ but the fundamental significance of commuting was only proved by their research on the educational policies of 100 towns and cities in 2011. Their hypothesis was that in Hungarian towns and cities the ethnic segregation of primary schools is strongly related to the proportion of Roma pupils attending primary schools, the segregating or integrative nature and effect of local educational policy, and the amount of residential segregation. Survey results confirmed the first two hypotheses, but, astonishingly, found that residential segregation has NO direct impact on level of school segregation. There is also a significant association between the level of local educational segregation and the commuting rate of high-status students. This means that the commuting rate is so high that it can neutralize the previously assumed impact of residential segregation on the level of school segregation (Kertesi - Kézdi 2013). Accordingly, the selection process is predominantly regulated by the willingness to commute of middle-class students.

\section{Main research questions}

The novelty of my study is that it attempts to map and interpret the trends and direction of pupils' commuting across catchment areas in a large city for the first time. This article is based on three comprehensive periods of data collection ${ }^{7}$ conducted in 2007, 2009 and in 2014 in all primary schools of Pécs. Data collection concentrated on the presumed motivation, direction, and the success of different pupil groups in commuting, the commuting balance of the catchment areas of primary schools, and the "commuting games" of schools (Neumann - Zolnay 2008; Zolnay 2010). The research questions of my third and second survey were designed to take forward the above-mentioned nationwide representative survey conducted in 2011 (Kertesi Kézdi 2013).

Therefore, my core research questions concerned whether the vast majority of commuter pupils really manage to attend higher status schools, and whether only a small proportion of low-status pupils commute to schools outside their catchment area. More generally, the study focused on whether the school selection process is regulated predominantly by "white flight"; that is, the mutual choice of prestigious schools and high-status pupils. If white flight does not exclusively regulate the commuting process, nor indirectly shape the selection mechanism of public education, then two relevant

5 In urban settlements, less than 25 percent of lower-status students (whose mother's education lasted a maximum of eight grades) commuted to a school other than their catchment school, while in the case of higher-status students (whose mothers had completed 12 grades or more) the rate was 50 percent.

6 In towns with only a few schools, fewer than 20 percent of middle-class students commuted. In towns with 10 schools, the proportion was over 40 percent, and 60 percent in towns with 40 schools.

7 The first study was conducted in the framework of EÖKiK (Public Foundation for European Comparative Minority Research), while its successor, CEC (Civitas Europica Centralis Foundation) (http://www.cecid.net/en/about-us), supported the second study. 
additional questions must be raised. How can we characterize the commuting patterns of different pupil groups, and how successful are the former in their efforts to find and enrol in schools better than their own catchment schools? What kind of school strategies can be identified in terms of the balance of their commuting inflow and outflow, and what kind of strategies do schools use to improve their positions and enhance their real or perceived interests?

I used the school's results in the National Assessment of Basic Competences as an indicator of school quality. I do not suppose that the majority of parents are well aware of the National Competence Assessment scores of primary schools, not to mention their added value indexes, but I do contend that parental choice via pupil commuting can be approached by taking a rational choice perspective. Consequently, I assume that the school choice of Roma parents is similarly driven by the motivation of finding primary schools perceived as better quality.

\section{Methods}

The study included all primary public schools and all pupils attending the public primary schools of Pécs. ${ }^{8}$ I collected data about the number of all pupils from each school, grade and class, specifying disadvantaged and multiply disadvantaged pupils, pupils with special educational needs, pupils with learning difficulties, and pupils perceived as Roma by the schools. Thereafter I identified the catchment area of each pupil. ${ }^{9}$ This database allowed me to map the commuting patterns of school catchment areas for each pupil group. I could assess which schools attracted commuting pupils in each category and where these pupils commuted from. I ranked the primary schools based on the data from the national competence assessment which allowed me to assess the success and direction of pupil movements in each pupil category and the bargaining positions of the schools.

The criteria defining the categories of disadvantaged, multiply disadvantaged pupils, pupils with special educational needs, and pupils with learning difficulties are statutory. Roma pupils are not registered officially and formally but the researchers' experience is that principals are acutely aware of who is Roma; likewise, non-Roma parents are keenly aware of alleged ethnic proportions, irrespective of the selfidentification of pupils. Tolerated ratios vary city-to-city and even by neighbourhood. In assessing the proportion of Roma pupils, I used the method of expert classification.

Besides quantitative data collection, I conducted detailed interviews with school principals about their schools and pupils and concerning the local educational bargaining in which they are involved.

8 In 2014, approximately 7800 pupils attended the 17 primary schools of the city.

9 I collected data anonymously, and data analyses were performed on aggregated data sets. 


\section{The priorities of the city's educational policy}

In recent decades the city's education policies have been driven by two consensual core principles. The municipality yielded to the pressure of middle-class parents who wished to enrol their children into the most prestigious schools of the city, and year after year permitted these schools to launch as many first-grade classes as possible, taking into account the building's capacity. Furthermore, the municipality which operated the schools wanted to prevent the development of serious segregation across schools and periodically closed segregating schools or ghettoizing school branches. Following the closure of the latter schools in 2007, the scale of segregation decreased for some years, but after a while the proportion of Roma pupils started to grow in certain schools until it reached a level at which white flight occurred. Outsourcing segregated primary school to church maintenance in 2013 has become the third element of the city's educational policy. Urban planning considerations usually do not significantly impact educational policy decisions due to the characteristics of the social history of cities (Erdősi 1968; Márfi 2005).

\section{Results}

\section{Segregation and commuting trends in Pécs}

The city has a significant Roma population of Beash (archaic Romanian-speaking) and Vlach (Romani-speaking) origin. During the communist era, most Roma families aimed to comply with forced assimilation requirements to such an extent that they exclusively talked in Hungarian with their children, so their native languages have almost totally vanished. Among primary school pupils, the proportion of Roma is 11 percent, which rate has been constant for a decade. The proportion of pupils with special educational needs was also 11 percent in 2014, of whom approximately 57 percent studied in mainstream schools while 43 percent attended special remedial schools. The proportion of pupils with learning difficulties studying in mainstream schools was 9 percent (see Table 1).

Table 1: Different pupil groups in the primary schools in Pécs (\%)

\begin{tabular}{c|c|c|c} 
Pupils & $\mathbf{2 0 0 7}$ & $\mathbf{2 0 0 9}$ & $\mathbf{2 0 1 4}$ \\
\hline Disadvantaged pupils & & 29 & 23 \\
\hline Roma pupils & 11 & 11 & 11 \\
\hline Multiply disadvantaged pupils & 4 & 6 & 4 \\
\hline Pupils with special educational needs & & & 11 \\
\hline Pupils with learning difficulties & & & 9
\end{tabular}

Sources: EÖKiK and CEC data collection

Following a period of sharp increase, the extent of ethnic segregation has declined significantly in state schools in recent years (see Table 2 and Table 3 ). The commuting rates for primary school students slightly differed from the data measured nationwide. 
The rate of commuting students was similar but, unexpectedly, the proportion of multiply disadvantaged students and Roma students attending primary school outside their catchment area was significantly higher than the average rate observed in large towns (see Table 4). However, surprisingly, the commuting rate of low-status students increased during the period when school segregation declined.

Table 2: Average dissimilarity index of Roma pupils measured in each grade in 2007, 2009 2014 in Pécs

\begin{tabular}{c|c} 
Year & Average dissimilarity index (DI) of Roma pupils measured in each grade \\
\hline 2007 & $0,04-0,05$ \\
\hline 2009 & $0,08-0,09$ \\
\hline 2014 & $0,05-0,06$ \\
\hline
\end{tabular}

Sources: EÖKiK and CEC data collection

Table 3: Distribution of Roma pupils in classes according to the proportion of Roma pupils (\%)

\begin{tabular}{c|c|c|c|c|} 
& \multicolumn{4}{|c}{ Proportion of Roma pupils } \\
\hline Year & $\mathbf{0 - 2 5 \%}$ & $\mathbf{2 6 - 5 0 \%}$ & $\mathbf{5 1 - 7 5 \%}$ & $\mathbf{7 6 - 9 9 \%}$ \\
\hline 2007 & 45 & 34 & 18 & 3 \\
\hline 2009 & 42 & 28 & 20 & 10 \\
\hline 2014 & 36 & 44 & 14 & 5 \\
\hline
\end{tabular}

Sources: EÖKiK and CEC data collection

Table 4: Proportion of commuting pupils in different pupil categories in Pécs (\%)

\begin{tabular}{cccc}
\hline & \multicolumn{3}{c}{ Proportion of commuting pupils } \\
\hline Pupils & 2009 & 2014 & $\begin{array}{c}\text { Except those who attended } \\
\text { special schools in 2014 }\end{array}$ \\
\hline All pupils & 58 & 58 & 54 \\
\hline Disadvantaged pupils & 52 & 53 & 50 \\
\hline Roma pupils & 39 & 51 & 29 \\
\hline $\begin{array}{c}\text { Multiply } \\
\text { disadvantaged pupils }\end{array}$ & 37 & 37 & 35 \\
\hline $\begin{array}{c}\text { Pupils with special } \\
\text { education needs }\end{array}$ & n.a. & 72 & 60 \\
\hline $\begin{array}{c}\text { Pupils with learning } \\
\text { difficulties }\end{array}$ & n.a. & 60 &
\end{tabular}

Sources: EÖKiK and CEC data collection 


\section{School types based on the inflow and outflow rates of different pupil categories}

We identified the catchment area of commuting students and defined several school types on the basis of the inflow and outflow rates of different pupil categories.

We called those schools "undesirable schools" which have fewer students, fewer multiply disadvantaged students, and fewer Roma students than the proportion living in the catchment areas; in other words, the commuting balances are negative in the case of each student group. Apparently, all pupils, including prestigious and low-status students, are equally trying to escape from these schools. The illusory confidence of school principals that their positive relations to their neighbourhood might enhance their prestige is groundless; undesirable schools only manage to raise their student numbers when the maintainer "outsources" educational segregation by transferring the maintenance and the financial sources to a church, or, less commonly, to an NGO. Such undesirable schools should be obliged to enrol all students living in their catchment area even in the latter case, since in principle no one is compelled to attend a church-maintained school. But if there is a less prestigious (churchmaintained) school nearby, undesirable schools make every effort to "persuade" the highest proportion of Roma families to choose the former because they wish to demonstrate that they also have the potential to select children.

We call "ghetto schools" those primary schools which have fewer students overall than those living in their catchment area but in which multiply disadvantaged and Roma students are over-represented in comparison to their representation in their catchment area. The student commuting balance is negative in total, but in the case of multiply disadvantaged and Roma students, the rate is positive. In other words, these schools are undesirable to primary school students in general, but they are quasi "attractive" to low-status students who practically have no choice in the school market. Ghetto schools are aware that their existence depends on the inflow of multiply disadvantaged and Roma students from outside their catchment area. Therefore they cannot afford to reject anyone.

We term "selective schools" those primary schools which overall have more students than those living in their catchment area, but fewer multiply disadvantaged and Roma students compared to the proportion expected in light of their catchment area. The student commuting balance is positive in total, but for multiply disadvantaged and Roma students the rate is negative. These schools are very attractive throughout the city, but nonetheless they reject many students who live in their catchment area whom they should be obliged to enrol without any further consideration. In practice, they do this by indirectly discouraging them and persuading them to choose other schools. A significant proportion of multiply disadvantaged and Roma students are rejected and displaced to less prestigious primary schools elsewhere in the city. Besides their quality and specialist curricula (for example, bilingual education), an important part of their hidden portfolio is that they can "guarantee" that middle-class children will not have Roma, or very poor classmates. "Selective schools" have few or no ties to the 
neighbourhood, or may even seek to reduce their relationship with their immediate residential environment to a minimum. Their actual enrolment district is the whole city, and they can place anyone.

We use the term "attractive schools" for those primary schools which have more students and more multiply disadvantaged students and also more Roma students than their expected numbers in light of their catchment area; here, the commuting balances are positive in the case of each student group. These schools are attractive to all pupils, including prestigious and low-status students.

Pre-selective school: Twenty years ago, two schools and five pre-schools launched a joint preschool-primary school programme. Connecting pre-school education groups and primary school classes, the same teachers (who hold dual teacher-kindergarten qualifications) teach children from the age of three to ten. The main purpose of this programme is to facilitate the transition of children from preschool to primary school. However, the prestige of the two primary schools has started to diverge and it has become more and more important into which of the five preschools children can be enrolled because preschool choice determines in which school a child can continue their studies.

Table 5: Distribution of pupils among different types of primary schools: inflow and outflow rates of different pupil groups in Pécs in 2014 (\%)

\begin{tabular}{c|c|c|c|c|c|c} 
& $\begin{array}{c}\text { All } \\
\text { pupils }\end{array}$ & $\begin{array}{c}\text { Disadvantaged } \\
\text { pupils }\end{array}$ & $\begin{array}{c}\text { Roma } \\
\text { pupils }\end{array}$ & $\begin{array}{c}\text { Multiply } \\
\text { disadvantaged } \\
\text { pupils }\end{array}$ & $\begin{array}{c}\text { Pupils with } \\
\text { special } \\
\text { education } \\
\text { needs }\end{array}$ & $\begin{array}{c}\text { Pupils with } \\
\text { learning } \\
\text { difficulties }\end{array}$ \\
\hline Undesirable schools & 18,8 & 21,3 & 31,0 & 45,1 & 20,9 & 22,2 \\
\hline Ghetto schools & 6,8 & 10,1 & 18,8 & 14,4 & 6,0 & 8,5 \\
\hline Selective schools & 27,3 & 13,5 & 3,0 & 2,2 & 8,2 & 22,0 \\
\hline Attractive schools & 23,6 & 25,8 & 15,5 & 3,7 & 10,0 & 22,2 \\
\hline $\begin{array}{c}\text { Outsourced } \\
\text { segregated school }\end{array}$ & 1,0 & 3,7 & 10,5 & 3,9 & 6,8 & 16,1 \\
\hline Pre-selective school & 15,6 & 18,7 & 8,0 & 19,1 & 1,8 & 5,8 \\
\hline Special school & 4,7 & 2,6 & 10,1 & 10,2 & 43,3 & 0 \\
\hline Other schools & 2,2 & 4,3 & 3,1 & 1,4 & 3,0 & 3,2 \\
\hline Total & 100 & 100 & 100 & 100 & 100 & 100
\end{tabular}

Sources: Data collection by CEC

We divided the city's primary schools into quintiles based on their national competence assessment performance. Highly selective schools are located in the highest quintile. The primary schools ranked into the second quintile cannot be categorized clearly, but in general they can be described as slightly undesirable. Attractive schools fell into the third school quintile; and undesirable schools fell into the fourth school quintile, while the lowest quintile contained the ghetto schools. 
Table 6: Distribution of Roma pupils across school quintiles of The National Competence Assessment in 2014 (\%)

\begin{tabular}{c|c|c|c|c|} 
& \multicolumn{2}{|c|}{ All pupils } & \multicolumn{2}{c|}{ Roma pupils } \\
\hline & $\begin{array}{c}\text { Living in } \\
\text { catchment areas } \\
(\%)\end{array}$ & $\begin{array}{c}\text { Attending schools } \\
(\%)\end{array}$ & $\begin{array}{c}\text { Living in catchment } \\
\text { areas (\%) }\end{array}$ & $\begin{array}{c}\text { Attending schools } \\
(\%)\end{array}$ \\
\hline 1. (The highest) & 11,6 & 20,2 & 10,1 & 2 \\
\hline 2. & 28,4 & 26,2 & 11,3 & 8,1 \\
\hline 3 & 9 & 20,6 & 8 & 19 \\
\hline 4. & 19,9 & 17,1 & 41,3 & 29,8 \\
\hline 5. (The lowest) & 21,1 & 11,3 & 23,5 & 30,9 \\
\hline $\begin{array}{c}\text { Pre-selective } \\
\text { school }\end{array}$ & 10,2 & & 5,7 & \\
\hline Special school & & 4,7 & & 10,1 \\
\hline
\end{tabular}

Sources: Data collection by CEC

\section{Commuting games in the city}

Each school assumes that the size, social composition and urban status of its catchment area decisively influences its prestige and position in the local educational market. Based on the finding of a survey that assessed the educational policy of 100 cities and towns in 2011 (Kertesi - Kézdi 2013), this false assumption can be considered the fundamental "spatial perception" of primary schools which largely determines their enrolment policy. Three corresponding institutional strategies can be identified in Pécs.

Preventive strategy: Schools situated in slum areas want to avoid a further increase in the proportion of Roma pupils and therefore the possible closure of even less prestigious schools nearby seems to be the greatest threat to them. They generally consider the size of their catchment zones to be irrelevant.

The municipality attempted to close a segregated ghetto school located near the largest shanty town/segregated area of the city several times, but the preventive strategy of the neighbouring schools proved to be successful: the school principals worried about the consequences and successfully lobbied the municipality to prevent this occurring. One year before the nationalization of primary and secondary schools, the mayor of the city made it clear that the ghetto school was to be closed soon unless the school principal "found" a church or a foundation that would be willing to take over the maintenance of the school. The school principals approached the local pro-government MP to intervene on their behalf. The MP was happy to help, and "convinced" the Roman Catholic Church to take over the school's maintenance despite its former reluctance. Segregation outsourcing became a new, previously unknown element of local education policy. The surrounding schools were thus able to avert the 
"threat" that pupils of the ghetto school might "overwhelm" them, but each school's status continued to deteriorate. The number of pupils declined drastically; the proportion of Roma and multiply disadvantaged pupils increased, and more children living in their vicinity seemed to prefer other primary schools. Nonetheless, these schools sustained their strategy.

Manoeuvring astutely in local politics, school principals of two "threatened" undesirable central institutions were successfully able to prevent the proposed closure of their small, segregated branch schools, but nevertheless they could only slow down the outflow of students from their catchment areas, and did not manage to stem the further decline of their status. Gentrification of local neighborhoods did not increase the school's attractiveness either.

A significant number of commuting multiply disadvantaged and Roma pupils living near undesirable schools enrolled into ghetto schools. These schools are "the winners" of the "commuting game" - but only as long as they are indifferent towards the social and ethnic composition of their schools. The continuous decline of these schools' prestige and their student population may induce a change in their strategy. The largest ghetto school in the city desperately tried to improve its music education to make itself more attractive, and also attempted to introduce a selective admission policy. However, they lacked the preconditions for selective recruitment and their student numbers further decreased. Finally, the school principal and the maintainer chose to invite the Roman Catholic Church to take over the school. In this case, the final aim was not to "outsource" segregation (the proportion of Roma pupils was about 23 percent and the school is far from being segregated), but rather to displace low-status pupils and to increase the school's prestige. However, due to this the "preventive game" of the surrounding schools has restarted.

Isolation strategy: Highly prestigious schools with catchment areas that also comprise slum neighborhoods or disreputable streets wish to further decrease the already low rate of pupils living in their vicinity and to isolate themselves from their urban environment even more. In the case of a school closure nearby, their aim is to minimize the number of students they have to take in.

The largest segregated school was situated close to the historic centre of the city and its catchment area was adjacent to the catchment districts of the two most prestigious primary schools that were also comprised of slum neighborhoods. The two prestigious elite schools successfully isolated themselves from their vicinity; nevertheless, they were anxious about the eventual closure of the segregated school. That fear proved to be irrational due to the extremely low proportion (10-26 percent) of pupils of the latter living in their vicinity. However, these schools consider each other as mutual rivals. 
Pécs was the European Capital of Culture in 2010, ${ }^{10}$ and a major construction project started not far from the segregated school. A concert hall and a cultural centre were built, and the famous Zsolnay porcelain factory was converted and rebuilt as a cultural and educational complex. Currently, it accommodates several departments of the University of Pécs. However, on three sides the whole neighbourhood is surrounded by urban slums and even miserable Roma settlements. It was evident that the gentrification of the surrounding neighbourhood would start soon and a decision about the immediate closure of the segregated school was motivated by urban planning considerations. This was the only occasion when a primary school closure was firmly incited by urban planning goals.

The splitting of the catchment area and the allocation of pupils who had been attending the segregated school was the subject of a kind of a barter deal. The two highprestige elite schools did not have any other choice but to acknowledge and accept that they had to share most of the catchment area of the former segregated primary school, but they were not willing to enrol and accommodate the Roma pupils of the area. These schools were convinced that they simply could not afford to admit Roma pupils at all due to their exceptional prestige and high reputation. They assumed - not without reason - that they would be able to refuse or avoid admitting any undesirable pupils living in the slum area associated with their catchment area, just as they had earlier.

On the other side of the historic city centre, relatively far away from the closed, segregated school and situated in an old and beautiful building, there is a primary school that was threatened with closure due to a drastic decrease in the student population. This school received the pupils from the closed segregated school in the hope that it could thereby stabilize its position. These expectations were met only partially, because having been made aware of the decision, almost as many pupils left the school and chose to enrol elsewhere as many pupils arrived from the segregated school. The proportion of Roma pupils was not higher than 25 percent, but this proved to be more than the amount that the middle class was willing to tolerate in this urban environment. Moreover, the newcomers were stigmatized merely because they had attended the "ill-famed" segregated school. However, this game is also full of uncertainties. As the number of pupils continuously declines, closure of the school is just a matter of time. In this case, the "barter deal" might backfire: the two highly prestigious schools that shared the catchment area of the former segregated school will still be forced to admit pupils living in the slum neighbourhood.

Area-enlarging strategy: Primary schools situated in socially homogeneous neighborhoods, usually in the middle of large housing estates, attempt to increase their catchment areas when a neighbouring school is closed or when catchment area boundaries are being redrawn.

10 Three cities were chosen to be the European Capitals of Culture in 2010: Essen, Pécs, and Istanbul. 
In Pécs, housing estates are socially more homogeneous than neighborhoods that encompass older buildings, suburbs, former miners' colonies, or poor Roma settlements. The primary school situated in the southern part of the largest of the giant housing estates has a specific position. Fifteen years ago, the school moved towards specializing in the inclusive education of pupils with special educational needs and learning difficulties. As a result, the number of pupils and the school's prestige declined steadily. The catchment area of the school comprises a village-like neighbourhood where some wealthy carter Roma families ${ }^{11}$ live. Even though the proportion of Roma pupils is not higher than 13 percent, the school's reputation is very poor and nearly 70 percent of pupils living nearby have opted to attend other schools in the inner part of the huge housing estate, about eight to ten bus stops away. Recently, the school drastically changed its enrolment policy and attempted to improve its image by refusing to admit pupils with special needs living outside its district. Other school principals in the area of the housing estate shuddered nervously due to the influx of pupils arriving from the former school.

Before nationalization, the municipal maintener decided to close the smallest school in the giant housing estate and to split its catchment area among neighbouring schools. These neighbouring schools competed fiercely to add as many streets and blocks as possible to their district. Their area-increasing strategy was just the opposite of the isolation strategy of elite schools. All three large rival schools have maintained their positions during the last decade and the vehemence of the struggle over the streets is hard to understand, even when all three schools are recruitment rivals. The vast majority of pupils of the three schools commute and live outside their districts. Two of them have entered into an informal coalition and agreed to split some nearby streets, but in vain. Eventually, they both lost out on the "area-enlarging game." The largest, most influential complex which includes not only two primary schools but also five kindergartens and several secondary institutions obtained the majority of the "disputed" area.

However, for pupils it remains uncertain whether the decision is favourable, because the two primary schools belonging to the complex have a single catchment area, and they operate pre-selection practices. Thus, the educational trajectories of children are largely determined by their kindergarten choice at the age of three.

\section{The direction and success of pupil commutes}

I measured student mobility in two different ways. First, I measured in the case of each commuting pupil whether they attend better or worse schools compared to their catchment schools by ranking the city's primary schools based on their schools' national competence assessment performance data (I took into account their average results in the previous three years).

11 Transporters of coal, building material or furniture by horse cart or lorry. 
Most of the primary school pupils commute within the city and the majority of them attend better quality schools than their district schools. On the other hand, lowstatus commuters' efforts to find a better school than their district school is not only unsuccessful, but the majority of them end up attending worse quality schools than their respective catchment school. The failure of this commuting strategy is most striking in the case of Roma commuters, especially considering that 51 percent of all Roma pupils commute and opt for a primary school other than their catchment school. But even if we disregard those Roma pupils who attend the city's special school, 42 percent of Roma students still commute. Only 22 percent of commuting Roma pupils have managed to enrol in better quality schools than their district schools, 62 percent of them have chosen worse quality primary schools, and nearly 17 percent have been diagnosed as pupils with special educational needs who must not study in integrated, mainstream classrooms.

Table 7: The commuting direction of pupils into schools ranked by schools' results in the national assessment of basic competences in 2014 (\%)

\begin{tabular}{c|c|c|c|c} 
& $\begin{array}{c}\text { Attends better } \\
\text { quality school than } \\
\text { district school }\end{array}$ & $\begin{array}{c}\text { Attends worse } \\
\text { quality school than } \\
\text { district school }\end{array}$ & $\begin{array}{c}\text { Attends special } \\
\text { school }\end{array}$ & Total \\
\hline All pupils & 52,8 & 40,8 & 6,4 & 100 \\
\hline $\begin{array}{c}\text { Disadvantaged } \\
\text { pupils }\end{array}$ & 45,4 & 51,7 & 2,9 & 100 \\
\hline Roma pupils & 22,2 & 61,0 & 16,8 & 100 \\
\hline $\begin{array}{c}\text { Multiply } \\
\text { disadvantaged } \\
\text { pupils }\end{array}$ & 24,0 & 53,0 & 23,0 & 100 \\
\hline $\begin{array}{c}\text { Pupils with special } \\
\text { education needs }\end{array}$ & 24,9 & 23,8 & 51,3 & 100 \\
\hline $\begin{array}{c}\text { Pupils with learning } \\
\text { difficulties }\end{array}$ & 48,0 & 52,0 & 0 & 100 \\
\hline
\end{tabular}

Sources: Data collection by CEC

Second, I divided primary schools into quintiles based on their results in the national assessment of basic competences; this assessment is administered by the government annually (I took the average of the previous three years).

According to their motivation or compulsion; direction and success, we divided commuter pupils into several groups.

Pupils who successfully flee from low-status schools:

These pupils commute because they wish to attend better quality, more prestigious schools than their catchment school, and these families are not willing to accept Roma children as classmates or schoolmates. Their motivation can only be precisely described by the concept of "white flight." 
Pupils who successfully retain their high status: These pupils commute because they prefer to attend a prestigious school, although their catchment school is equally prestigious.

Unsuccessfully fleeing pupils: These pupils commute because they wish to attend a better, more prestigious school than their catchment school, but they ended up enrolling in a school whose quality is as poor as their catchment school.

Pupils excluded from a low-status school who enrol in segregated school: These pupils commute because they were "persuaded" to opt for a segregated church-run school instead of the district school which would be obliged to enrol them without any consideration.

Pupils excluded from high-status schools: These pupils commute because they were "persuaded" to opt for a much worse quality school instead of the prestigious district school which would be obliged to enrol them without any consideration. The most surprising and shocking finding is that families freely choose much worse quality schools than their catchment schools, and thereby opt for schools with significantly worse educational opportunities for their children. It is quite easy to exert pressure by indirect means on poor and ethnically stigmatized families with low self-esteem who cannot assert themselves sufficiently, and to "convince" and "persuade" them to make extremely disadvantageous decisions on behalf of their children.

Table 8: The commuting direction of pupils according to school quintiles in 2014 (\%)

\begin{tabular}{c|c|c|c|c|c|c} 
& All pupils & $\begin{array}{c}\text { Disadvantaged } \\
\text { pupils }\end{array}$ & $\begin{array}{c}\text { Roma } \\
\text { pupils }\end{array}$ & $\begin{array}{c}\text { Multiply } \\
\text { disadvantaged } \\
\text { pupils }\end{array}$ & $\begin{array}{c}\text { Pupils with } \\
\text { special } \\
\text { educational } \\
\text { needs }\end{array}$ & $\begin{array}{c}\text { Pupils with } \\
\text { learning } \\
\text { difficulties }\end{array}$ \\
\hline $\begin{array}{c}\text { Successfully } \\
\text { fleeing from } \\
\text { low-status } \\
\text { schools }\end{array}$ & 41.4 & 30 & 13.8 & 13 & 13 & 34.3 \\
\hline $\begin{array}{c}\text { Successfully } \\
\text { retaining high } \\
\text { status }\end{array}$ & 14.1 & 12.6 & 4.9 & 4 & 4.5 & 12.2 \\
\hline $\begin{array}{c}\text { Unsuccessfully } \\
\text { fleeing from } \\
\text { low-status } \\
\text { schools }\end{array}$ & 4.7 & 3.4 & 7.4 & 18 & 3.1 & 4.2 \\
\hline $\begin{array}{c}\text { Excluded from } \\
\text { prestigious } \\
\text { schools }\end{array}$ & 22.3 & 24.4 & 40.5 & 27 & 19.4 & 34.1 \\
\hline $\begin{array}{c}\text { Attending } \\
\text { special school }\end{array}$ & 6.4 & 3.9 & 17.7 & 23 & 51.3 & 0 \\
\hline
\end{tabular}

Sources: Data collection by CEC 


\section{Conclusion}

The majority of commuter pupils in Pécs end up in higher status, better quality schools. However, my findings did not confirm the nationwide urban trends that just a small proportion of low-status pupils commute (Kertesi - Kézdi 2013). In the examined city it is not true that the selection process is dominantly influenced by the "white flight" phenomenon, or in other words, by the mutual choices of prestigious schools and high-status pupils. In addition, the displacement of poor and Roma pupils from prestigious schools is an equally important factor in urban segregation.

In an urban environment, the higher the prestige of the school, the greater the geographical scope from where it can recruit pupils. This is exactly the opposite of the findings in the British literature which describe how the most popular schools have the smallest catchment areas (Hamnet and Butler 2010). The more selective a school is, the more it displaces the unwanted, the poor, and above all, Roma children. But while the undesirable schools try to maintain ties with their catchment area and hope that the gentrification of neighborhoods will increase their prestige, selective schools attempt to diminish all ties to their surrounding environment.

Not only do the school maintainers and the recently created central educational authorities have limited opportunities to keep the process under control, but school strategies are also uncertain. Even if it is assumed that school principals are accurately aware of the commuting balance of their own school and other schools' catchment areas for each pupil group, their different perceptions of residential environments hinder the stabilization of pupils' distribution among schools. In this respect, "bounded rationality" means that the unpredictability of pupil recruitment compels primary schools to do everything at all cost to attract more pupils who will presumably enhance their reputation, and to refuse those who might spoil it. The extreme selectivity of Hungarian public education is a self-perpetuating process not only in terms of parental choice, but also in terms of school enrolment policies.

Large-scale educational commuting fragments the urban space: boundaries cannot be drawn on a map because they are variable in the case of each school and each pupil. Any educational policy which uses regional targeting is bound to fail. The education map of the city is thus "illegible." 


\section{References:}

Ball, S. - Bowe, R. S - Gewirtz, S (1995): Markets, choice and equity in education. Buckingham: Open University Press.

Berényi, E. (2016): Az autonómiától a szelekcióig. Az iskolaválasztás jelentése a rendszerváltás utáni időszak magyar közoktatásában. Budapest: Gondolat.

Csapó, B. - Fejes, J. B. - Kinyó, L.- Tóth, E. (2014): Az iskolai teljesítmények alakulása Magyarországon nemzetközi összehasonlításban. In Kolosi, T., Tóth, I. Gy. (szerk.) Társadalmi Riport. Budapest: Tárki, 110-136. http://old. tarki.hu/adatbank-h/kutjel/pdf/b327.pdf

Dupcsik, Cs. (2009): A magyarországi cigányság története. Történelem a cigánykutatások tükrében 1890-2008. Budapest: Osiris.

Erdősi, F. (1968): A pécsi városszerkezet fejlődése és a városrészek funkcióinak alakulása a kapitalizmus korában. Pécs: MTA Dunántúli Tudományos Intézet (Közlemények 6.)

Fehérvári, A. (2015): Lemorzsolódás és a korai iskolaelhagyás trendjei. Neveléstudomány 3 (3): 31-47. http://nevelestudomany.elte.hu/downloads/2015/nevelestudomany_2015_3_31-47.pdf

Fehérvári, A. - Imre, A. - Tomasz, G. (2010): Az oktatási rendszer és a tanulói továbbhaladás In Balázs, É. - Kocsis, M. - Vágó, I. (szerk.): Jelentés a Magyar közoktatásról. Budapest: Oktatáskutató és Fejlesztő Intézet 133-196. http:// mek.oszk.hu/12800/12893/12893.pdf

Fiske, E. B. - Ladd, H. F. (2000): When schools compete. A cautionary tale. Washington DC: Brookings Institution Press

Hamnet, Ch. - Butler, T. (2010): 'Geography matters': the role distance plays in reproducing educational inequality in East London. Transactions of the Institute of British Geographers 36 (4): 479-500.

Havas, G. - Zolnay, J. (2011): Sziszifusz számvetése. Az integrációs oktatáspolitika. Beszélő 16: (6): 24-49. http://beszelo.c3.hu/cikkek/sziszifuszszamvetese

Hsieh, Ch. T. - Urquiola. M. (2006): The effects of generalized school choice on achievement and stratification: Evidence from Chile's voucher program. Journal of Public Economics 90 (8-9): 1477-1503.

Kemény, I. - Janky, B. - Lengyel, G. (2004): A magyarországi cigányság 19712003. Budapest: Gondolat - MTA Etnikai és Nemzeti Kisebbségkutató Intézet.

Kertesi, G. - Kézdi, G. (2009): Általános iskolai szegregáció Magyarországon az ezredforduló után. Budapest: MTA Közgazdaságtudományi Intézet. (Budapesti Munkagazdaságtani Füzetek, BWP 2009/6) http://econ.core.hu/file/ download/bwp/BWP0906.pdf

Kertesi, G. - Kézdi, G. (2010): Iskolázatlan szülők gyermekei és roma fiatalok a középiskolában. Beszámoló az Educatio Életpálya-felmérésének 2006 
és 2009 közötti hullámáról. In Kolosi, T. - Tóth, I. Gy. (szerk.): Társadalmi Riport. Budapest: Tárki 371-406. http://www.tarsadalomkutatas.hu/kkk. php?TPUBL-A-926/publikaciok/tpubl_a_926.pdf

Kertesi, G. - Kézdi, G. (2013): School segregation, school choice and educational policies in 100 Hungarian towns Budapest: Roma Educational Fund. http:// www.romaeducationfund.hu/sites/default/files/publications/school_segregationschool_choice_and_educational_policies_-_final_2013.pdf

Kertesi, G. - Varga, J. (2005): Foglalkoztatás és iskolázottság Magyarországon. Közgazdasági szemle 52 (7-8): 633-662. http://www.econ.core.hu/doc/bwp/ bwp/Bwp0501.pdf

Kovai, M. - Neumann, E. (2015): Hová lett az egyenlősítő közoktatás? A komprehenzív iskolareform sorsa Angliában és Magyarországon 1945-től a nyolcvanas évekig. Educatio 24 (4): 65-78.

Márfi, A. (2005): A pécsi cigánykolóniák a tanácskorszakban 1950-1990. Pécsi Szemle 8 (2): 86-101.

Mártonfi, Gy. (2014): Korai iskolaelhagyás - hullámzó trendek. Educatio 23 (1): 36-49. http://www.hier.iif.hu/hu/educatio_reszletes.php?id=99

Musset, P. (2012): School Choice and Equity: Current Policies in OECD Countries and a Literature Review. OECD Education Working Papers, No. 66. Paris: OECD Publishing. http://dx.doi. org/10.1787/5k9fq23507vc-en

Neumann, E. - Zolnay, J. (2008): Esélyegyenlőség, szegregáció és oktatáspolitikai stratégiák Kaposváron, Pécsen és Mohácson. Budapest: Európai Összehasonlító Kisebbségkutatások Közalapítvány. (Műhelytanulmány 38.) https:// www.scribd.com/doc/46660526/Eselyegyenloseg-szegregacio-es-oktataspolitikai-strategiak-Kaposvaron-Pecsen-es-Mohacson

OECD (2015): Education policy outlook Hungary http://www.oecd.org/education/Hungary-Profile.pdf

OECD (2017): School choice and school vouchers: An OECD perspective. http://www.oecd.org/education/School-choice-and-school-vouchers-anOECD-perspective.pdf

Ostorics, L. - Szalay, B. - Szepesi. I. - Vadász, Cs. (2016): PISA 2015. Összefoglaló jelentés. Budapest: Oktatási Hivatal. https://www.oktatas.hu/ pub_bin/dload/kozoktatas/nemzetkozi_meresek/pisa/PISA2015_osszefoglalo_jelentes.pdf

Papp, Z. A. (2015): Iskolai eredményesség és a roma tanulói arány összefüggésrendszere az OKM adatok alapján https://kisebbsegkutato.tk.mta.hu/ uploads/files/pappz_ea.pdf

Radó, P. (2014): A Nemzeti Együttmüködés Közoktatási Rendszere és a PISA mérések. http://beszelo.c3.hu/onlinecikk/a-nemzeti-egyuttmukodes-kozoktatasi-rendszere-es-a-pisa-meresek 
van Zanten, A. (2008): Competitive arenas and schools' logics of action: a European comparison. Compare 39 (1): 85-98.

Zolnay, J. (2010) „Olvashatatlan város”. Közoktatási migráció és migrációs iskolatípusok Pécsen. Esély 21 (6): 41-65. http://www.esely.org/ kiadvanyok/2010_6/04zolnay.indd.pdf 